\title{
O 18 BRUMÁRIO E A ANÁLISE DE CLASSE CONTEMPORÂNEA
}

Renato Monseff Perissinotto

A análise de classe, isto é, a análise que pretende entender os fenômenos sociais e políticos a partir das relações entre classes sociais situadas no processo produtivo, é um dos pilares teóricos do marxismo. Uma das tarefas da análise de classe, segundo Ralph Miliband, é "demonstrar as estruturas e os mecanismos exatos de dominação e exploração" nas sociedades humanas (1996: 483). Para ser mais específico, o marxismo tem como obrigação não apenas identificar as relações de exploração que se estabelecem, ao longo da história, entre produtores e proprietários dos meios de produção, mas, também, na medida em que atribui às relações de classe a condição de princípio estruturador da totalidade social, analisar os "mecanismos de dominação" por meio dos quais as classes atuam na política. Nesse caso, o problema teórico fundamental, para usar as palavras de Przeworsky, "resume-se em saber como um grupo de indivíduos ocupantes de lugares torna-se uma coletividade em luta para a realização de seus interesses" (1989: 86).

Este artigo tem como pretexto inicial um retorno à mais consagrada análise histórica de Marx - O 18 Brumário 
de Louis Bonaparte - para tentar identificar nessa obra como as classes se fazem representar na luta política. O uso de O 18 Brumário não se deve a uma excentricidade acadêmica. Acredito que essa obra se constitui em uma espécie de súmula que condensa todas as dificuldades inerentes à análise de classe da política ${ }^{1}$ e, a meu ver, ainda presentes na literatura marxista contemporânea, como se pretende mostrar no decorrer deste trabalho. Nesse sentido, o objetivo mais geral deste texto é ver como a literatura contemporânea enfrentou o problema teoricamente fundamental para a análise política de classe, isto é, o problema de pensar a classe como ator político e não apenas como um lugar objetivo nas relações de produção.

Para tanto, o artigo está dividido em cinco partes. Na primeira, o objetivo é descrever e analisar as passagens de O 18 Brumário que enunciam algumas proposições fundamentais acerca da análise política de classe, apresentan82 do, logo em seguida, uma síntese das principais críticas a essas proposições, notadamente aquelas elaboradas por Mancur Olson. Na segunda parte, pretendo mostrar que a literatura marxista contemporânea não resolveu o problema central que consiste em saber como é possível pensar a classe como "ator político", apesar de algumas tentativas nessa direção. As terceira e quarta partes do texto discutem algumas perspectivas alternativas de análise política (classistas e não classistas) ao marxismo, buscando identificar suas contribuições e críticas à análise de classe. Por fim, à guisa de conclusão, fazemos algumas reflexões sobre modos possíveis de operacionalizar a aná-

\footnotetext{
${ }^{1}$ Nesse sentido, O 18 Brumário de Louis Bonaparte é um texto mais "completo" que $O$ capital. Nessa obra, como se sabe, encontramos apenas referências aos lugares objetivos (no processo produtivo) que constituem as classes sociais fundamentais do modo de produção capitalista. Para usar a expressão de Ruy Fausto, em O capital encontramos apenas as "classes em inércia". Cf. Fausto, 1987: 203. Ver também Sallum, 2005.
} 
lise de classe da política e sobre os problemas a serem enfrentados nesses casos.

\section{Análise de classe e processo político em 018 Brumário}

$\mathrm{O}$ aspecto mais interessante de $O 18$ Brumário é o fato de Marx, nessa obra, propor uma análise de classe da política sem, contudo, reduzir a dinâmica da luta política à dinâmica dos interesses econômicos imediatos de classe. Essa análise classista, mas não reducionista, da política aparece em quatro momentos do texto, apresentados e comentados a seguir.

O primeiro deles, e talvez o mais evidente, refere-se à existência de grupos politicamente estratégicos que não têm uma base produtiva e, portanto, não se constituem em classes sociais na acepção marxista do termo. Refiro-me aos republicanos burgueses do National que, segundo Marx, não são uma "fração da burguesia mantida coesa por grandes interesses comuns e delimitada por condições peculiares de produção. Era uma camarilha de burgueses, escritores, advogados, oficiais e funcionários de idéias republicanas” ([1852]1984: 33), cujo objetivo político fundamental era a instauração da República ([1852]1984: 34). No entanto, se essa clique de republicanos não constitui uma classe, por que então adjetivá-los de "burgueses"?

A resposta a essa questão exige tratar do segundo tema em que, a meu ver, se evidencia a análise não reducionista da política em O 18 Brumário. Segundo Marx, os republicanos não eram "burgueses" por causa do seu vínculo econômico, mas sim em função de uma "visão de mundo" que via a "ordem burguesa” como a única ordem social possível. Nesse sentido, os republicanos burgueses são representantes de classe não em função dos interesses econômicos imediatos que defendem, mas pela "ideologia" que professam. A "representação de classe", nesse caso, não é vista como um exercício de ventriloquia, em que o representado manipula o representante, obrigando-o a verbalizar os 
seus interesses no interior das instituições políticas. Essa perspectiva analítica aparece explicitamente em outras duas importantes passagens: a primeira, quando Marx analisa a representação pequeno-burguesa na Assembléia Nacional Legislativa ([1852]1984: 55); a segunda, quando se refere à famosa distinção entre "burguesia parlamentar" e "burguesia extraparlamentar" ([1852]1984: 109).

Nessas passagens, Marx refere-se aos "representantes políticos e literários de uma classe”, expressão que, a meu ver, visa a conjugar o lugar estratégico que as classes sociais ocupam, na sua explicação, com a idéia de autonomia da representação política. A representação política da burguesia e da pequena burguesia não se faz por meio da presença direta de lojistas e grandes capitalistas no interior da Assembléia Legislativa, que atuariam como porta-vozes dessas classes, buscando em cada caso, em cada assunto, em cada lei e projeto discutidos promover os seus ganhos econômi84 cos imediatos. Na verdade, a representação de classe reside numa “correspondência” de "visões de mundo" que leva os "representantes políticos e literários" (ou a parte da classe que "fala e escreve") da pequena burguesia e da burguesia a se colocarem problemas e soluções que são, em termos gerais, os mesmos que habitam o mundo real dessas classes. Essas passagens são ainda mais interessantes porque revelam que esses representantes podem estar a "um mundo de distância” ([1852]1984: 55) da situação vivida pelos membros da classe que representam. Isso sugere, portanto, que tais visões de mundo podem ser absorvidas e sistematizadas a partir de posições sociais outras que não a posição da classe representada no processo produtivo.

Em O 18 Brumário de Louis Bonaparte, Marx, ao pensar a estratégia revolucionária frente ao aparelho de Estado, avalia que "todas as revoluções aperfeiçoavam esta máquina [centralizada do Estado] em vez de a destruir" ([1852]1984: 125). De acordo com o seu receituário revolucionário, é 
preciso destruir o aparelho estatal, pois este não é mais visto como um aparelho neutro.

A tese de que o aparelho estatal traz inscrito na sua própria organização interna a natureza de classe da sociedade em que ele opera sugere uma outra: para que o Estado atenda aos interesses da classe dominante, não é condição necessária que os membros dessa classe "controlem" os cargos estatais. Há várias passagens em O 18 Brumário de Louis Bonaparte em que Marx parece dar-se conta de que o Estado burguês e a sociedade burguesa mantêm entre si uma relação que transcende as influências subjetivas que a burguesia e seus membros possam eventualmente exercer sobre os agentes do aparelho estatal (ver, por exemplo, [1852]1984: 67, 109, 125 e 133). De acordo com essas passagens, o Estado cumpre a "função objetiva" de garantir a ordem material da sociedade burguesa sem que, para tanto, seja necessário que a burguesia esteja à frente do leme do Estado.

Por fim, as classes aparecem como atores que agem racionalmente (Maguire, 1984) em um dado contexto político-institucional que, por sua vez, afeta a estratégia desses mesmos atores classistas. Nesse sentido, podemos encontrar em O 18 Brumário aquilo que Antoine Artous (1999: 168) chamou de "dialética das formas políticas". Segundo esse autor, a análise que Marx faz do período que vai de 1848 a 1851 revela que o movimento das formas políticas não é o reflexo mecânico da vontade das classes sociais; ao contrário, não raro, são as classes que buscam adaptar-se às novas condições políticas produzidas à sua revelia.

De fato, uma análise atenta de O 18 Brumário mostra que não é a burguesia unificada que constrói a república, mas o advento da república que permite a unificação da burguesia; não são os interesses parciais de determinadas frações burguesas que produzem a crise da república, mas a crise da república que, ao recolocar na ordem do dia a possibilidade de uma restauração monárquica, gera crises no interior da 
burguesia; não é a burguesia que reivindica o fim da república e o golpe de 1851, mas a paralisia decisória produzida pelos embates entre os representantes políticos da classe burguesa que leva essa classe a aderir ao golpe; numa palavra, não são apenas as estratégias das classes que afetam a configuração das formas políticas, mas também a configuração das formas políticas afeta o movimento estratégico das classes (ver, por exemplo, [1852]1984: 27-28 e 99-101).

As considerações feitas por Marx em O 18 Brumário de Louis Bonaparte indicam três maneiras de operacionalizar a análise de classe no processo político: uma primeira, que poderíamos chamar de "representação objetiva de classe"; uma segunda, que poderíamos identificar como "representação simbólica de classe"; e uma terceira, que vamos chamar de "representação subjetiva de classe".

A "representação objetiva de classe" (no caso, dos interesses burgueses) faz-se presente por meio de um Estado 86 crescentemente autonomizado, mas que não abandona a sua "função objetiva" de reprodução da ordem social, isto é, um Estado que reproduz a ordem burguesa à revelia da própria burguesia. Essa visão de representação sugere que a classe social deve ser tratada não como um agente político consciente de seus interesses (i.e., como um "ator coletivo"), mas como uma "realidade objetiva" que se impõe à dinâmica política independentemente das vontades dos seus membros e de seus representantes. Visto que essa "representação objetiva de classe" não trata a classe social como um "ator político" presente, direta ou indiretamente, nos embates da política cotidiana, não é nosso propósito abordá-la neste texto ${ }^{2}$.

\footnotetext{
${ }^{2}$ Essa forma de operacionalizar a representação de classe, como se sabe, foi amplamente aprofundada pela literatura "neomarxista", em especial, por aquela dedicada à teoria do Estado capitalista. Quanto a esse ponto, cf. Poulantzas, 1986; Offe, 1984; Offe e Ronge, 1984; Block, 1987; Holloway e Picciotto, 1978. Pareceme que a grande vantagem dessa perspectiva está em propor uma "sociologia dos
} 
A "representação simbólica de classe" aparece quando Marx se dedica a pensar a "afinidade simbólica” existente entre a visão de mundo dos representantes políticos e literários da burguesia e da pequena burguesia e os interesses dessas classes. Como vimos, tanto em um caso como em outro, a parte da classe que "fala ou escreve" não exerce a sua função de representação como porta-voz direto da classe, mas sim como portadora de uma visão de mundo que, na sua essência, contribui para reproduzir a ordem social ou para vocalizar na arena política interesses de classe, ainda que não apresentados explicitamente como tais.

A "representação subjetiva de classe" indica que as classes se fazem presentes na cena política, direta ou indiretamente, como atores políticos que perseguem seus objetivos de classe conscientemente. Lançando mão de um modelo de ação fundamentado na racionalidade instrumental, Marx entende que as classes têm fins políticos claramente definidos e que buscam realizar seus objetivos fazendo opções estratégicas em situações de escolha. Às vezes, parece sugerir que a classe age diretamente, por meio de referências à burguesia, à pequena-burguesia e ao proletariado como atores políticos coletivos; outras vezes, refere-se aos líderes políticos e aos partidos como portavozes de classe na cena política.

As duas perspectivas que aqui nos interessam, no entanto, apresentam problemas para serem operacionalizadas. As críticas feitas à representação simbólica apontam para as dificuldades de comprovar a existência de relações de representação simbólica de classe que não

efeitos das decisões políticas" e, a partir dela, detectar o caráter de classe do Estado capitalista. No entanto, como já apontado por vários autores, essa abordagem sofre, em geral, de um rígido funcionalismo e de um grau de abstração excessivo que comprometem seriamente o seu rendimento analítico. Para essas críticas, ver Miliband, 1983; Cohen, 1982; Elster, 1982; Roemer, 1982. 
são vivenciadas como tal pelos "supostos" representantes da classe. Em suma, a questão aqui é a seguinte: como é possível comprovar que um determinado discurso ou uma dada visão de mundo correspondem, a despeito das intenções subjetivas de quem os formula, a determinadas posições objetivas de classe? Essa será a questão essencial das discussões teóricas realizadas, por exemplo, por Bourdieu e Klaus Eder, mas está praticamente ausente da literatura marxista contemporânea, como se verá mais adiante.

As críticas feitas à representação subjetiva de classe pretendem mostrar a impossibilidade de a classe constituir-se voluntariamente em um ator coletivo. Mancur Olson, em A lógica da ação coletiva, revela que um dos erros das teorias que lançam mão da ação coletiva para explicar os fenômenos sociais e políticos é pressupor que a lógica da conduta individual se aplica também à ação coletiva. Essas teorias 88 parecem admitir que, se um indivíduo isolado e consciente de seus interesses persegue os seus objetivos racionalmente, então vários indivíduos, colocados em uma situação semelhante, percebendo a similaridade dos seus interesses, agirão coletivamente para realizá-los da melhor forma possível. Como mostra Olson, se mantivermos o pressuposto da racionalidade individual, perceberemos que, em grandes grupos, a saída mais racional é sempre a abstenção, frustrando-se, assim, o surgimento voluntário de ações coletivas nesses grupos. Dessa forma, a classe estaria impedida de transformar-se, diretamente, em um ator coletivo (Olson, 1999, cap. 4).

Nesse caso, porém, os autores marxistas poderiam objetar, dizendo que nem eles nem Marx defenderam a tese de que as classes sociais agem diretamente na política, como forças coletivas voluntárias (Therborn, 1989). Na verdade, as classes agiriam sempre por meio de "porta-vozes", isto é, por meio de sindicatos, partidos, igrejas e outras insti- 
tuições, que falariam em nome das classes. Como é fácil perceber, o problema empírico que se coloca aqui é: como provar que tais instituições de fato veiculam os interesses das classes em questão? Trata-se de tarefa fundamental, sob pena de transformarmos tal relação de representação em um mero pressuposto.

Por fim, é importante lembrar que essas duas maneiras de operacionalizar a análise de classe da política tocam no problema fundamental da definição dos "interesses de classe" e da apresentação de procedimentos pelos quais tais interesses possam ser identificados e analiticamente operacionalizados. Seja definindo a representação de classe por meio de afinidades simbólicas, seja entendendo-a como uma ação política conscientemente levada pela classe ou por instituições que falam em seu nome, o fato é que, nos dois casos, se exige do analista que o "interesse de classe" seja adequadamente (i.e., convincentemente) identificado para que a relação de representação seja comprovada.

\section{A teoria marxista hoje: os problemas permanecem}

Correndo o risco de ser excessivamente superficial, creio que podemos identificar, na literatura marxista contemporânea, quatro grandes correntes que fornecem diferentes compreensões acerca de como operacionalizar o conceito de classe social para a análise política. A primeira delas é a perspectiva estruturalista, cujo autor paradigmático é Nicos Poulantzas; a segunda corrente é aquela contida nos trabalhos mais recentes de Eric Olin Wright, representante do que poderíamos chamar de uma perspectiva "cartográfica" das classes sociais; em terceiro lugar, temos E. P. Thompson que, situando-se no pólo oposto à teoria estruturalista, elaborou uma visão "subjetivista" da classe social; por fim, ocupando uma posição intermediária entre as correntes acima listadas, podemos 
citar a perspectiva da "formação de classe", cujo representante mais importante seria Adam Przeworsky. Vejamos, a seguir, cada uma delas.

Para Nicos Poulantzas, a classe social deve ser pensada como um efeito do conjunto das estruturas sobre os agentes. Em termos muito gerais, podemos dizer que, para esse autor, a prática (econômica, política e ideológica) de classe e os limites dentro dos quais essas práticas variam são efeitos estruturais. Por conseguinte, os limites da intervenção das práticas sobre as estruturas são também definidos objetivamente pelas mesmas estruturas sociais. Convém lembrar que também o conceito de interesses de classe é definido como um efeito estrutural. Interesses de classe são interesses objetivos que se constituem numa espécie de horizonte estrutural de classe. Assim, se a classe é o efeito da estrutura sobre os agentes, se as práticas de classe se inserem no interior dos limites fixados pela estrutura, o interesse de 90 classe só pode indicar esses limites estruturais à prática de classe, isto é, a extensão do campo de ação de uma classe, definido pelo seu lugar objetivo no conjunto das estruturas sociais (Poulantzas, 1986: 107-108).

Uma das vantagens da abordagem poulatziana, reconhecida inclusive pelos seus críticos, reside na importância atribuída às dimensões não-econômicas das classes sociais. Desse modo, as classes e a luta de classes não poderiam ser compreendias sem referências ao político e ao ideológico. Por essa razão, Poulantzas desenvolveu, com base nos textos históricos e políticos de Marx, conceitos propriamente políticos para pensar a luta política entre as classes, tais como "frações de classe", "bloco no poder", "fração autônoma de classe", "efeito pertinente", "classe reinante", "classe detentora", "fração hegemônica" e "categoria social". Quanto a esse ponto, Adam Przeworsky observa que esse autor desenvolve "um grande número de categorias taxionômicas por intermédio das quais 
pode-se identificar efeitos políticos das classes sem examinar sua organização" (Prezeworsky, 1989: 88, grifo nosso). De fato, as considerações de Poulantzas no que se refere às classes sociais nada dizem sobre a sua transformação em "ator político coletivo", pois, por um lado, esse autor preocupa-se em identificar apenas os "efeitos objetivos" que a estrutura de classe produz na esfera política e, por outro, as "funções objetivas" que as instituições políticas, notadamente o Estado, cumprem quanto aos "interesses objetivos" das classes.

Por conseguinte, sob uma perspectiva estruturalista torna-se muito difícil pensar o problema da "transformação social". Na verdade, fica-se impossibilitado de enunciar-se teoricamente a questão da organização e da ação de classe, pois o objeto de estudo privilegiado deve ser as estruturas sociais e não a prática das classes ou o seu processo de organização. Por essa razão, a ênfase que Poulantzas confere, em alguns de seus escritos (por exemplo, 1978: 11-38), às práticas e à luta de classes assume apenas função retórica, sem que esses temas sejam de fato aprofundados pelo autor.

Eric Olin Wright, no seu livro Classe, crise e o Estado, discute, entre outras coisas, a importância de formular conceitos que permitam, no âmbito da teoria marxista, pensar a relação entre a estrutura de classes e a prática das classes nas lutas políticas conjunturais. Com a intenção de pensar sobre esse problema, ele formula os conceitos de "capacidades estruturais", "capacidades organizacionais de classe" e "formação de classe". Os dois primeiros conceitos descrevem as relações sociais que vinculam, de forma objetiva, os agentes em uma situação comum de classe. A capacidade estrutural refere-se à posição objetiva de classe no processo produtivo capitalista e funciona como elemento que modela a capacidade da classe para a auto-organização consciente de seus membros. A tra- 
dução das capacidades estruturais em capacidades organizacionais depende da luta de classes e descreve mais especificamente o processo, necessariamente histórico, de "formação de classe".

Nesse sentido, para Wright, a luta de classes não é uma variável dependente, apenas modelada por causas estruturais (como seria na perspectiva poulantziana), mas afeta diretamente a capacidade das classes e, portanto, o seu processo de formação. Isso, por sua vez, gera impactos sobre a reprodução/transformação das estruturas dentro das quais agem as classes. Enfim, a luta de classes é o conceito que estabelece a mediação entre a estrutura de classe e o processo de formação de classe, isto é, o processo de transformação da classe em ator coletivo (Wright, 1979: 91-100) ${ }^{3}$.

Wright, no entanto, não aprofundou tais considerações e não revelou nenhuma nova estratégia metodológica 92 que pudesse fazer o marxismo avançar no estudo do processo de transformação da classe em ator político coletivo. Preocupado em adequar a análise de classe às sociedades capitalistas contemporâneas (e, assim, reagir àqueles que afirmam a falência teórica do marxismo em função do desaparecimento das classes sociais), Wright redirecionou todo o seu esforço teórico para produzir um mapeamento da estrutura de classe atual, lançando mão de conceitos como "controle", "exploração" e "localização contraditória de classe" (Wright, 1979, 1985, 1993 e 1996; e Roemer, 1989). Como observa Lafferty, a abordagem de Wright preocupa-se fundamentalmente em fornecer uma categorização das classes a partir do seu lugar nas relações de controle e exploração. Esse tipo de análise tende, portanto, a diluir a importância da dimensão política da análise marxista de classe (Lafferty,

\footnotetext{
${ }^{3}$ Para um resumo mais completo da teoria das classes sociais de Wright, cf. Santos, 2002.
} 
1996: 62) e, por via de conseqüência, a não colocar seriamente o problema da transformação das classes em atores políticos coletivos.

Esse, na verdade, não é um problema restrito ao trabalho de Wright. A literatura marxista mais recente temse limitado, em geral, a mapear a estrutura de classe das sociedades capitalistas avançadas e a redefinir o conceito de classe de modo que se adequasse melhor à realidade dessas sociedades (Myles e Turegun, 1994; e Grusky e Sorensen, 1998). Como pouco ou quase nada se diz sobre o processo por meio do qual a classe se transforma em ator político, parece que o mapeamento da estrutura de classe constitui-se em um fim em si mesmo ${ }^{4}$, sem que se estabeleça nenhuma conexão entre ela e o comportamento de classe $^{5}$ (Grusky e Sorensen, 1998: 18).

\footnotetext{
${ }^{4}$ Esse já era o diagnóstico de Therborn, anos atrás, quando, ao fazer a crítica da teoria estruturalista, se referia ao "grave problema teórico que nunca foi diretamente enfrentado, o do agente de classe". Therborn, 1989: 436, grifo nosso. Ver também Myles e Turegun, 1994: 7, e Sallum, 2005: 25. No caso do Brasil, o estudo empírico mais portentoso da estrutura de classe da sociedade brasileira feita nos últimos anos abre mão de analisar o processo de formação de classe. Santos tem razão ao dizer que a análise da estrutura de classe precede logicamente o est udo do processo de formação da classe. Cf. Santos, 2002: 31. O fato, entretanto, é que quase nenhum esforço empírico tem sido realizado nesse sentido pelos marxistas, o que sugere dificuldades de operacionalizar o conceito de classe como um ator político. Nesse sentido, é surpreendente que um livro intitulado La teoría marxista hoy: problemas y perspectivas, publicado em 2006, não traga um único texto dedicado a pensar no problema da operacionalidade do conceito de classe para a análise da política. Cf. Gonzáles, 2006.

${ }^{5}$ Esta ausência, de qualquer forma, é coerente com a recusa de Wright em atribuir às relações de classe a primazia na explicação dos demais conflitos sociais e políticos. Cf. Wright, 1998: 703 e ss. É preciso observar, entretanto, que transformar a relevância da análise de classe num problema de ênfase não parece resolver o problema. É certo que diminuímos as exigências colocadas sobre a teoria das classes sociais se trocamos a afirmação "a classe explica tudo" pela afirmação "a classe explica algumas coisas eficientemente, outras, nem tanto e outras, simplesmente não explica". No entanto, ao menos para o marxismo, não é indiferente o que o conceito de classe é capaz de explicar. Por exemplo, se este conceito explica a impermeabilidade das fronteiras de classe isso faz dele certamente um importante conceito econômico, mas se ele não explica nada, ou muito pouco, da luta política, isso afeta negativamente a importância da análise de classe em termos marxistas, já que para essa teoria a classe não é apenas um conceito econômico,
} 
Posição diametralmente oposta às duas perspectivas resumidas acima é ocupada por E. P. Thompson. Em The making of the english working class, quase toda a atenção de Thompson volta-se para o processo histórico por meio do qual a "classe acontece", isto é, os modos pelos quais os homens vivenciam experiências comuns, sentem e articulam sua identidade e seus interesses, contrapondo-os à identidade e interesses de outros homens. Dessa forma, a única maneira de definir classe e captar a sua existência concreta é por meio do estudo dessa "experiência” e não mapeando a estrutura objetiva de classe (1987: 10-12). Por meio do termo "experiência”, o autor crê recuperar "homens e mulheres" como sujeitos que vivem determinadas condições objetivas, mas que também tratam essa experiência em sua consciência e cultura e, em seguida, agem sobre as condições objetivas (Thompson, 1981: 183).

Dois são os problemas dessa abordagem. O primeiro deles já foi apontado por Perry Anderson em Teoria, política e 94 história. Resumidamente, Anderson afirma que, ao recusar o estruturalismo e o marxismo vulgar, Thompson cai no extremo oposto. Apesar de sua manifestação explícita de adesão ao materialismo histórico, o fato é que, na sua obra, a classe passa a ser definida quase que exclusivamente em função de sua consciência e passa a ser considerada como tal somente após o surgimento de uma identidade coletiva (1985: 36-37). Conseqüentemente, um dos maiores problemas da abordagem thompsoniana é pressupor que a luta de classe só surge depois que homens e mulheres tomam consciência do seu pertencimento de classe (Lafferty, 1996: 57).

Apesar dessas críticas, o ganho certamente teria sido grande não fosse o segundo problema desse tipo de abordagem: apesar da ênfase na "experiência", Thompson não

mas a unidade analítica a partir da qual podemos entender a essência da dinâmica política. Nesse sentido, a questão fundamental é a seguinte: é possível pensar a classe como "ator político"? Para essa questão não encontramos, ainda hoje, uma resposta convincente. 
resolve efetivamente o problema de saber como um conjunto de homens que partilham uma dada posição se transforma em ator político coletivo. Ou seja, esse autor permanece, em última análise, dentro de uma teoria de tipo "caixa preta" ${ }^{6}$. Aqui, o argumento de Olson revela toda a sua força. Como vimos, de acordo com esse autor, ainda que os membros de uma classe produzissem uma consciência de si e uma disposição para agir coletivamente, a abstenção seria o resultado inevitável. Percebe-se, portanto, que nem mesmo o conceito de "experiência", com toda a sua ênfase na dimensão subjetiva de classe, daria conta da ação coletiva. Assim, não basta dizer, como faz Wood na sua defesa da perspectiva thompsoniana, que "é no meio dessa experiência vivida que toma forma a consciência social e, com ela, a 'disposição de agir como classe'”(2003: 89-90). Mesmo nessas condições absolutamente favoráveis, em que a similaridade da condição objetiva se traduz em consciência dessa similaridade e, portanto, em disposição para agir, a classe não será, necessariamente, um ator coletivo. Mesmo nessas condições favoráveis, "a classe não aconteceria".

Temos, por fim, aqueles que defendem uma posição intermediária entre as perspectivas vistas acima, ao proporem uma "teoria do processo de formação da classe", cujo representante mais importante é Adam Przeworsky ${ }^{7}$ O

\footnotetext{
${ }^{6}$ Os teóricos da ação coletiva que se apóiam no individualismo metodológico diriam que a seqüência explicativa marxista poderia ser representada da seguinte forma: condição objetiva de classe $\rightarrow$ consciência de classe $\rightarrow$ ação coletiva. Tratar-se-ia de uma explicação com base em uma teoria do tipo "caixa preta", isto é, preocupada com as grandes associações macrossociológicas. Esse tipo de teoria seria incapaz de revelar os micromecanismos por meio dos quais, por exemplo, uma posição objetiva dá origem a indivíduos conscientes dessa posição e que, por sua vez, sentem-se motivados a engajarem-se em uma ação cooperativa. As flechas presentes na representação gráfica acima só poderiam ser explicadas por teorias do tipo "caixa translúcida", dedicada exatamente a revelar como determinadas posições objetivas se traduzem em comportamento individuais. Quanto a este ponto, cf. Wippler, 1993: 208-209.

${ }^{7}$ Outro autor que se refere explicitamente à necessidade de elaborar uma teoria do processo de formação de classe sem, contudo, formulá-la de fato é Göran Therborn, 1983.
} 
“processo de formação da classe" refere-se à constituição da classe em força política e ideológica engajada na luta concreta. Essa teoria parte de dois princípios teóricos.

O primeiro deles consiste na rejeição categórica da problemática marxista da classe-em-si/classe-para-si. Segundo Przeworsky, de acordo com essa problemática, o processo de formação da classe é visto como uma transição necessária e mecânica da classe-em-si para a classepara-si. Conseqüentemente, uma vez mapeada as posições objetivas de classes, a classe-em-si, poderíamos identificar os diversos tipos de classe-para-si apenas por um processo de derivação. Como se percebe, por essa visão, o processo concreto pelo qual uma classe se transforma em ator político organizado e coletivo jamais pode transformar-se em um objeto de estudo privilegiado, visto que ele já está explicado de antemão (1989: 67-85). Como diz o autor, o que essa visão não explica é "como um grupo de indi96 víduos ocupantes de lugares torna-se uma coletividade em luta para a realização dos seus interesses objetivos" (1989: 86).

Para Przeworsky, só há uma maneira de resolver esse problema, qual seja, defender claramente a tese de que "as classes não são determinadas unicamente por quaisquer posições objetivas porque constituem efeitos de lutas, e essas lutas não são determinadas exclusivamente pelas relações de produção" (1989: 86). O processo de formação da classe dependerá, de um lado, das condições objetivas que estruturarão os limites da luta de classes (i.e., que definem uma estrutura de escolhas dadas em um determinado momento histórico) e, de outro lado, do desenvolvimento (dinâmica, sentido, profundidade) da luta concreta entre as classes (suas decisões, estratégias, alianças) numa situação histórica específica. Desse modo, somente os limite colocados ao processo de formação de classe são conhecidos a priori. Conclusões 
sobre o seu desenvolvimento real só podem ser formuladas pelos estudos empíricos da luta entre as classes em uma sociedade concreta e, nesse sentido, é um processo em grande parte indeterminado.

O segundo ponto de partida da teoria de Przeworsky refere-se ao método escolhido para o estudo do processo de formação de classe, a saber, o individualismo metodológico. Esse método implica abandonar o procedimento teórico pelo qual se deriva diretamente a classe-para-si da classe-em-si. Devemos, ao contrário, entender as relações sociais como estruturas de escolhas disponíveis aos agentes e, nesse sentido, o individualismo metodológico não pressupõe que uma dada ação surgirá, necessariamente, por uma dada condição objetiva. Ao contrário, exige que uma ação coletiva coordenada seja explicada em termos de opções individuais feitas pelos membros de um agregado social. Por essa razão, como lembra Prezerworsky, "encontramos imensa dificuldade na compreensão da política em termos de classe" (1989: 119). Assim que abandonamos o pressuposto de que uma ação coletiva surgirá, necessariamente, de uma dada posição de classe, isto é, assim que nos propomos a explicar aquilo que antes era tomado como pressuposto, percebemos que entender a vida política pela categoria "classe social" se torna algo muito complexo, pois é muito difícil, como nos lembra Olson, que agregados sociais tão grandes ajam coletivamente da maneira espontânea como se pensava antes. Essa, talvez, seja a razão pela qual, no texto citado de Przeworsky, encontramos apenas referências muito genéricas à necessidade de estudar o processo de formação da classe sem uma indicação precisa de como fazê-lo.

\section{Alternativas classistas ao marxismo: a visão culturalista}

Frente aos problemas presentes na teoria marxista das classes sociais, parte da teoria social contemporânea defendeu a validade científica desse conceito, desde que se rompesse com a sua visão marxista. Essa perspectiva, que podemos chamar de 
"culturalista”, é representada por dois autores teoricamente muito próximos: Pierre Bourdieu e Klaus Eder.

Segundo Pierre Bourdieu ${ }^{8}$, uma nova definição de classe social deve começar rompendo com o marxismo em quatro dimensões: a) evitar a ilusão intelectualista, que consiste em confundir a "classe teórica" com a "classe real"; b) abandonar o economicismo, que apregoa uma visão unidimensional que não leva em conta os efeitos dos campos não-econômicos na constituição das classes sociais; c) refutar o objetivismo, que menospreza a luta simbólica de classe, isto é, a luta pelo poder de impor a percepção legítima do mundo; e, por fim, d) evitar a tendência a ver as classes sociais como uma substância, em favor de uma visão relacional que defende que os atributos de uma classe são definidos a partir de sua relação com outras classes. Para redefinir o conceito de classe social, Bourdieu propõe pensá-lo pela articulação de quatro conceitos: "espaço social”, "campo", "capital" e "posição social”.

O conceito de espaço social descreve a sociedade como um todo formado por várias dimensões organizadas segundo princípios de diferenciação social próprios e cujas lógicas são irredutíveis umas às outras, ainda que interligadas. Essas dimensões, que compõem o espaço social, são chamadas de "campo". Esse conceito, por sua vez, designa um conjunto de relações de forças objetivas, que definem as posições sociais dos agentes em função do quantum de capital (e poder) que eles controlam. Cada campo tem uma lógica específica, isto é, regras próprias que regulamentam a luta pela posse de um capital também específico. Nesse sentido, da mesma forma que podemos falar de "campo econômico", "campo político", "campo cultural", podemos também nos referir aos capitais específicos desses campos: capital econômico, capital político, capital cultural. A quantidade de capital possuída por um

\footnotetext{
${ }^{8}$ O resumo feito a seguir lança mão dos seguintes textos: 1989, 1989a, 2001, 2003 e 2004.
} 
agente expressa os atributos da posição objetiva que ele ocupa no campo e, dessa forma, o poder (ou a falta dele) que define a sua capacidade (objetiva) de produzir ganhos naquele campo. Assim, por exemplo, o volume de capital cultural determinaria as probabilidades de ganho em todos os jogos em que o capital cultural fosse importante. Os agentes sociais, portanto, ocupam posições sociais diversas em campos diversos. Dessa forma, para definir objetivamente a posição de um agente no espaço social, precisamos levar em consideração o volume global e a estrutura (composição) do seu capital. Não basta, por conseguinte, identificar a quantidade global de capital que ele possui, mas é preciso também avaliar o peso relativo das diferentes espécies de capital que compõem o seu "patrimônio".

Conseqüentemente, vários agentes pertencem à mesma classe social se ocuparem as mesmas coordenadas no interior do espaço social (e não apenas dentro de um campo específico). Assim, indivíduos que ocupam a mesma posição no campo econômico, mas posições muito distintas no campo cultural, não pertencem à mesma classe social. Eis, aqui, a multidimensionalidade do conceito de classe defendida pelo autor. Quanto a esse ponto, é preciso concordar com Eder (2002, cap. 4) que a maior novidade trazida para a teoria das classes sociais por Bourdieu, e que se evidencia na maior parte dos seus trabalhos empíricos, é a introdução do "capital cultural" como critério absolutamente fundamental para a definição de classe social nas sociedades contemporâneas ${ }^{9}$. Vinculado a isso, a dimensão simbólica

\footnotetext{
${ }^{9}$ Ver, por exemplo, La noblesse d'État. Segundo Bourdieu, o capital cultural assume três estados: capital cultural interiorizado, isto é, conhecimento maior ou menor da língua culta, gostos e estilos de vida internalizados ao longo da vida familiar; capital cultural objetivado, materializado em bens culturais tais como livros, quadros e monumentos e que dependem, para serem apreciados, da posse de capital cultural interiorizado; por fim, capital cultural institucionalizado, que existe por meio de diplomas escolares. Cf. Bourdieu, 2001. Na medida em que o capital cultural define posições sociais e destinos sociais semelhantes, ele deve ser, para esse autor, um critério fundamental na definição das classes sociais.
} 
da luta de classes passa a ser central na sua teoria. Nesse sentido, o que está essencialmente em jogo na luta política entre as classes é a luta para impor as categorias de percepção do mundo social. Na medida em que toda produção simbólica, para Bourdieu, expressa relações de força entre as classes, a luta simbólica é a luta pelo poder de conservar ou transformar o mundo social (e a distribuição de capital que lhe corresponde), conservando ou transformando a percepção desse mundo.

No entanto, a classe assim definida - indivíduos que ocupam posições semelhantes no espaço social - não é sinônimo de ator coletivo, pois, como vimos, é preciso evitar a ilusão intelectualista que confunde posições objetivas com a existência de atores coletivos conscientes. Essas posições objetivas semelhantes geram apenas "probabilidades" de que as atitudes, os interesses, as práticas e a tomada de posição dos indivíduos sejam semelhantes. Nesse sentido, é 100 preciso diferenciar a "classe no papel" (ou classe provável) - uma classificação meramente teórica que permite identificar a probabilidade de comportamentos semelhantes ocorrerem na prática - da "classe real" - um grupo mobilizado para a luta.

Entretanto, o fato de a posição objetiva não se traduzir necessariamente em um ator coletivo consciente de seus interesses não quer dizer que ela não seja uma "coletividade”. Segundo Bourdieu, indivíduos que ocupam as mesmas posições no espaço social muito provavelmente partilham o mesmo habitus de classe, isto é, o mesmo conjunto de "predisposições duráveis" que são internalizadas pelos agentes submetidos a processos de socialização semelhantes. Essas predisposições duráveis, interiorizadas coletivamente, orientam a conduta dos agentes no mundo e geram reações semelhantes às circunstâncias enfrentadas pelos membros de uma mesma classe. Essa semelhança de conduta, porém, não é vivenciada como uma ação coletiva 
consciente e coordenada. O habitus opera no nível infraconsciente e descreve muito mais uma "inconsciência de classe" do que o contrário.

No entanto, o conceito de habitus e a ênfase nos comportamentos coletivos inconscientes não impedem Bourdieu de pensar a classe como ator consciente no campo político e ele o faz por meio do conceito de "representação". Para ele, uma classe só existe como força real no campo político se tiver um representante. A questão fundamental aqui é resolver o mistério por meio do qual o "mandatário" recebe do grupo o poder de fazer o grupo, constituindo, dessa forma, o grupo como grupo real e constituindo-se a si mesmo como representante. Desse ponto de vista, a relação de representação é uma via de mão dupla: o grupo não age diretamente, mas concede a um porta-voz o direito de falar em seu nome; este, por sua vez, nunca é tão-somente um representante, pois, ao falar em nome do grupo, é capaz de instituí-lo como tal no campo político. Mas essa é sempre uma relação perigosa, ameaçada pelo que Bourdieu chama de "apropriação usurpadora", na qual o representante se distancia do grupo e passa a constituir-se no pólo mais poderoso da relação de representação, que, em função disso, deixa de existir. Nesses casos, a classe, até então representada, transforma-se em uma classe que só existe no pensamento e no discurso dos seus representantes (líderes, partidos, sindicatos, associações etc.).

Como se sabe, o campo político foi, na sociologia de Pierre Bourdieu, infelizmente, objeto apenas de considerações ensaísticas, diferentemente dos campos cultural, artístico e escolar. Quanto ao problema da representação política, o máximo que Bourdieu fez foi sugerir uma análise histórica de sua gênese e de seu funcionamento. Desse modo, embora a questão clássica sobre o processo pelo qual posições objetivas de classe se traduzem em atores coletivos organizados na luta política esteja presente 
em Bourdieu, esse autor não deu uma solução satisfatória para o problema ${ }^{10}$.

Um outro autor que discutiu esse problema sob uma perspectiva muito próxima da de Bourdieu (i.e., que leva em conta a dimensão cultural e simbólica da luta de classes) foi Klaus Eder (2002).

Eder propõe um modelo de três camadas pelo qual seria possível compreender a ação coletiva de classe (2002: 26). A primeira camada do modelo descreve a classe como uma estrutura e não como um agente. Eder deixa claro que devemos abandonar definitivamente a idéia da classe como ator: "as classes não agem, atores sim" (2002: 19). Nesse sentido, a classe é uma "determinação estrutural de oportunidades de vida" (2002: 33). A estrutura de classe, assim entendida, distribui determinados atributos (econômicos, educacionais e culturais) a um grande número de indivíduos que então poderiam ser classificados em classes sociais. Dessa forma, 102 como conjunto de pessoas portadoras das mesmas propriedades objetivas, a classe é apenas a base para uma "provável” ação coletiva. A segunda camada do modelo descreve a "textura cultural", isto é, os valores, as identidades e o conhecimento ligados à cultura de uma classe. A cultura "refere-se a qualquer tipo de expressão simbólica que dê sentido ao mun-

\footnotetext{
${ }^{10}$ Diferentemente de suas análises sobre o consumo, a distinção cultural e o acesso aos diplomas escolares consagradores, em que ele consegue estabelecer, com sucesso, relações entre posições objetivas de classe, formas de distinção e ganhos simbólicos diferenciados. Certamente, uma análise de classe da política segundo as proposições de Bourdieu teria muito a aprender com os trabalhos empíricos realizados por esse autor em outros campos sociais. O campo político parece ter, entretanto, algumas dificuldades adicionais. Primeiramente, é difícil delimitar claramente as "instituições" que fazem parte desse campo, a menos que adotemos a posição formalista que consiste em reduzi-lo às instituições de governo ou àquelas diretamente relacionadas à política; em segundo lugar, uma classe pode se fazer representar simbolicamente por meio de várias instituições e agentes ao mesmo tempo (sindicato, partidos, políticos profissionais, intelectuais orgânicos); terceiro, os discursos políticos, por causa da competição eleitoral, tendem a convergir para um tom cada vez mais moderado e a adotar um conteúdo cada vez mais vago, dificultando a sua distinção em termos de classe.
} 
do, à sociedade e a si próprio. Ela contém elementos (meios simbólicos) para expressar tal sentido e padrões estruturais que se organizam em conjuntos coerentes" (2002: 17, nota 1). Por fim, a terceira camada do modelo refere-se ao âmbito da ação social por meio da ação coletiva, entendida como ação coordenada orientada por estruturas de preferência (2002: 26). Nesse modelo, a cultura ocupa papel essencial, pois é ela quem faz a mediação entre o nível estrutural (classe) e o nível da ação (ação coletiva). Segundo Eder, não há ação de classe que passe diretamente à ação coletiva sem a intermediação de uma "textura cultural" (2002: 27) ${ }^{11}$.

Dito isso, como devemos operacionalizar esse modelo? Segundo o autor, devemos partir inicialmente da ação coletiva, visando a relacioná-la a espaços de ação simbolicamente definidos e, em seguida, perguntarmos qual é a conexão entre esses espaços de ação, simbolicamente definidos, e as diferenças de classe (2002: 31). Dessa forma, uma ação coletiva é de classe quando seu discurso se conecta a uma cultura que reproduz diferenças de classe (ou quando instaura novas diferenças). Seguindo a orientação culturalista de Bourdieu, Eder afirma que é somente por meio da luta simbólica que podemos procurar os mecanismos que transformam posições objetivas de classe em classes reais (2002: 155)

Por essa razão, Eder diz defender uma "teoria construtivista da classe social”. Essa teoria consiste em, de início, recusar categoricamente a classe como um fato social a priori (2002: 283). O autor afirma que só podemos falar de classe à medida que determinadas ações coletivas se constituem

\footnotetext{
${ }^{11}$ Segundo Eder, se as classes, sobretudo como definidas pelo marxismo, deixaram de ser um conceito importante para entender as sociedades contemporâneas, não é porque deixaram de existir objetivamente (ainda que sua importância relativa na estrutura de classe tenha diminuído significativamente), mas, sobretudo, porque elas perderam "valor cultural". As ações coletivas atualmente não mais se legitimam pelas posições de classe nas relações de produção. Cf. Eder, 2002: 19. A questão aqui é ver em que medida uma afirmação como essa pode ser generalizada para todos os países.
} 
simbolicamente, no próprio movimento da luta, como uma ação de classe. Diz ainda que o seu "construtivismo" pressupõe três conceitos estratégicos: a "agência", que descreve a capacidade de gerar definições coletivas de interesses, normas e valores por meio da ação coletiva; o "contexto", que se refere à arena dos conflitos sociais em que se situam as ações coletivas (2002: 282) e, por fim, o "efeito estrutural", que é o estudo dos efeitos objetivos que uma ação coletiva pode produzir sobre a estrutura de classe, reproduzindo-a ou transformando-a.

Desse ponto de vista, uma ação é de classe se: (i) a sua ação coletiva produz uma definição de interesses, normas e valores que possa ser relacionada a uma determinada posição objetiva de classe; (ii) se ela produz efeitos no sentido de (re)definir as divisões de classe de acordo com os interesses, normas e valores professados pela ação coletiva. Para Eder, esse é o elemento decisivo (2002: 294). Eder confere

104 mais importância aos efeitos estruturais da ação coletiva do que à ação coletiva propriamente dita, o que explicaria a pouca atenção dada pelo autor ao problema de sua gênese.

Creio que podemos fazer duas observações críticas em relação às proposições de Eder. Primeiramente, a pretexto de abandonar a visão marxista de classe, supostamente incapaz de dar conta da realidade atual, o autor fornece um conceito ultragenérico, cuja única função parece ser resguardar o termo "classe social". Ao definir classe como uma estrutura que distribui atributos a um conjunto de indivíduos que, por causa disso, partilham as mesmas oportunidades (ou falta delas) para agir e para viver, qualquer agregado social acaba sendo uma classe. Assim, os negros (cujas oportunidades de vida são definidas pela suas relações com os brancos) podem ser uma classe; as mulheres ${ }^{12}$

\footnotetext{
${ }^{12}$ Segundo Eder, "gênero e etnia são formas de relações e conflitos sociais em competição, mas essas são coletividades socialmente construídas com base em 'símbolos naturais'. As classes, ao contrário, existem como fatos sociais, isto é, como
} 
(cujos atributos dependem de sua relação com os homens) podem ser uma classe; pessoas que vivem uma mesma situação de risco (ainda que de origens sociais diversas) podem ser uma classe. Enfim, a recuperação da política de classe só é possível em função de um uso puramente nominalista no termo "classe". Eder parece ter consciência do problema e, mais adiante, opta por restringir o conceito e lançar mão da ocupação profissional e do capital cultural como os critérios objetivos para definir uma classe social (2002: 148-153). Essa estratégia parece ser mais adequada à sua interpretação dos novos movimentos sociais como mobilizações coletivas de classe média ${ }^{13}$.

Em segundo lugar, é inegável que Eder coloca claramente o problema da ação coletiva de classe. Na verdade, podemos dizer que a questão que perpassa todo o seu trabalho é a seguinte: como é possível comprovar empiricamente que uma ação coletiva é uma ação de classe? Ele sugere o seguinte procedimento para responder a essa questão: o analista deve comprovar os vínculos entre a cultura da ação coletiva e a estrutura de classes,

coletividades socialmente construídas com base em símbolos socialmente definidos. Esta é a diferença básica entre classe e qualquer outro critério que defina coletividade" (Eder, 2002: 293). A passagem acima é surpreendente! Como vimos, inicialmente classe é definida como uma "estrutura de oportunidade". Valendo-se apenas desse critério, etnia e gênero deveriam também ser classes, pois a oportunidade de vida das pessoas está intimamente ligada à estrutura das relações de gênero e raça da sociedade. Será que Eder negaria que os homens brancos têm mais oportunidades de vida do que as mulheres negras? Definir gênero e etnia como "atributos naturais" não apaga o fato de que ambos são dotados de significação social e que fora da sociedade não têm sentido em si mesmos. Por fim, dizer que a classe é um fato social consiste em formular uma afirmação simplesmente contrária ao que foi dito dez páginas antes, isto é, que "a classe não é um fato social". Cf. Eder, 2002: 283.

${ }^{13}$ Quanto a esse ponto, é curioso que Eder, por um lado, recuse a contradição entre burguesia e proletariado como importante para entender a sociedade moderna e, por outro lado, construa toda a sua definição de classe média/pequenaburguesia, lançando mão de um esquema ortodoxo que situa essa classe entre os proprietários e os não proprietários dos meios de produção. Ver Eder, 2002, capítulo 8, por exemplo: 239. 
procurando mostrar como a prática simbólica do grupo mobilizado reproduz ou altera a estrutura de classe da sociedade. O que o sociólogo deve analisar, portanto, são os "efeitos estruturais" que uma ação coletiva constituída por um dado contexto cultural produz sobre a estrutura de classe, isto é, se ela transforma ou conserva as categorias de percepção pelas quais essa estrutura é apreendida. Isso, como se percebe, é tão fácil de falar quanto difícil de fazer, e não há, em Eder, nenhuma indicação mais precisa de como operacionalizar essa proposição, isto é, como vincular um dado conteúdo simbólico a uma dada posição objetiva de classe. Creio, inclusive, que até aqui estamos no mesmo nível de generalização encontrado nas idéias de Marx sobre os "representantes políticos e literários de classe". Como vimos, o caráter de classe da ação política desses indivíduos é definido por meio de uma afinidade simbólica entre suas práticas políticas e culturais 106 e uma visão de mundo típica de uma classe. Enfim, creio que Eder, ao menos na obra citada, coloca claramente o problema da relação entre grupos mobilizados, ação coletiva e classe social, mas oferece muito pouco no que diz respeito às formas de operacionalizar as suas proposições culturalistas $^{14}$.

\footnotetext{
${ }^{14}$ Quanto a esse ponto, a parte mais interessante do trabalho é quando Eder se refere ao tipo de dados que as suas proposições teóricas exigiriam para serem comprovadas. Até onde pudemos entender, Eder sugere que, para identificarmos a base de classe de um movimento social, devemos coletar três tipos de dados: (i) dados sobre a estrutura de oportunidade em que os agentes da ação coletiva estão inseridos. Esse procedimento seria importante para situar o lugar objetivo da classe estudada; (ii) dados sobre as orientações culturais dos grupos mobilizados (i.e., os grupos promotores de ações coletivas coordenadas, que podem ser vários) em termos de "interesses", "normas" e "valores", e ver se há entre eles uma "unidade cultural" por cima da multiplicidade de objetivos específicos; (iii) por fim, fazer uma análise desses dados culturais para ver se eles reproduzem antigas classificações ou se definem novas, isto é, para ver se eles reproduzem a antiga estrutura de oportunidades ou se definem novas estruturas de oportunidade. Cf. Eder, 2002: 277-279.
} 


\section{Alternativas não classistas ao marxismo}

As dificuldades de operacionalização do conceito de classe social levaram duas outras correntes teóricas a se apresentarem como alternativas ao marxismo. De um lado, os teóricos "pluralistas", com sua ênfase no conceito de "grupo de interesse"; de outro, os teóricos das "elites políticas", que defendem esse conceito como o mais operacional para pensar o problema do "predomínio político".

Os teóricos pluralistas têm, basicamente, duas razões para defender a tese de que a vida econômica e política deve ser entendida, primordialmente, como esferas animadas por interações intergrupais (Truman, 1951: 11-41; Dahl, 1997, cap. 5; Kaplan e Lasswell, 1998, cap. 3; Olson, 1997, cap. 5; e Mclennan, 1989, caps. 1 e 2). A primeira delas é de natureza normativa. Para esses autores, pensar a vida social e política em termos de competição entre grupos sociais não é apenas recomendável, já que está de acordo com o funcionamento efetivo das coisas e mesmo com a natureza humana (Truman, 1951: 14), mas também desejável, pois é essa competição que confere à vida social equilíbrio e proteção ante o poder cada vez maior do Estado.

A segunda razão para se utilizar o conceito de grupo de interesse é de ordem metodológica e científica. Para os pluralistas, o conceito de grupo permite evitar três erros. Primeiramente, permite recusar as visões individualistas das sociedades expressas, por exemplo, nos teóricos do contrato social. Para Truman, os indivíduos nunca existem isoladamente, nunca são prévios aos grupos a que pertencem (1951: 16); em segundo lugar, esse conceito não implica pensar o coletivo como uma abstração externa aos indivíduos, que se impõem a eles de fora. Desse ponto de vista, como lembra Truman (1951: 29), trata-se de recusar categoricamente a oposição entre indivíduo e sociedade. O grupo transcende os indivíduos, mas, concretamente, um grupo é um conjunto de interações interindividuais reais; por fim, e pelas razões 
apontadas acima, o grupo é, para a maioria dos indivíduos, uma realidade muito mais significativa do que a classe social e a "sociedade" como um todo. Na verdade, esses dois grandes agregados, pela sua extrema amplitude, seriam pouco significativos para entender o comportamento humano.

Uma vez formado um grupo, pelas interações regulares entre os seus membros, ele pode ou não transformar-se em um "grupo de interesse". Para Truman, o termo "grupo de interesse" "refere-se a qualquer grupo que, com base em uma ou mais atitudes partilhadas, faz certas reivindicações frente a outros grupos na sociedade em favor do estabelecimento, manutenção ou consolidação das formas de comportamento implicadas por aquelas atitudes partilhadas" (Truman, 1951: 34-4). Ora, à medida que as sociedades se tornam mais complexas, surge uma pluralidade de grupos sociais que, mais cedo ou mais tarde, tornam-se grupos de interesse, isto é, grupos organizados e ativos que partici108 parão da vida social e política com vistas a defender seus interesses. Seria esse o processo responsável por animar a dinâmica da vida democrática ${ }^{15}$.

Entendido dessa forma, o conceito de "grupo de interesse" sofre de todos os problemas que Mancur Olson identificou na teoria da classe social (1999, cap. 5). De fato, não encontramos entre os pluralistas nenhuma explicação para o processo pelo qual uma similaridade de interesses se traduziria, necessariamente, em ação coletiva. Ou, valendo-nos das expressões utilizadas por Kaplan e Lasswell (1998: 60-

\footnotetext{
${ }^{15}$ Não é preciso ir até ao marxismo para fazer a crítica desse "paraíso pluralista". Schattschneider (1975) fez duas objeções fundamentais a esse esquema. Primeiramente, ele mostrou que o "sistema de grupos de pressão" nos Estados Unidos tem claramente um viés de classe, na medida em que só os grupos economicamente poderosos têm capacidade de se organizar e recursos para exercer pressão. Em segundo lugar, Schattschneider apontou o economicismo dessa visão, que, ao entender o sistema político como um procedimento de transformação de inputs em outputs, acaba menosprezando o processo político propriamente dito. Este, diz ele, baseia-se basicamente na tensão entre privatização e socialização dos conflitos, que pode alterar todo o resultado do processo político.
} 
61), nunca sabemos ao certo como a "solidariedade" (uma forma de pensar e sentir em conjunto) se traduz efetivamente em "cooperação" (uma forma de fazer em conjunto). Desse modo, o conceito de "grupo de interesse" não se constitui em uma alternativa ao conceito de classe social, pois sofreria da mesma incapacidade de explicar como um grupo se constitui em ator político ${ }^{16}$.

A perspectiva elitista, por sua vez, ao enfatizar as "minorias politicamente ativas" como os atores políticos que de fato contam, teria duas vantagens em relação aos conceitos de classe social e de grupos de interesse. Primeiramente, por dedicar-se ao estudo de um grupo pequeno, a teoria das elites não sofreria dos problemas lógicos encontrados naqueles conceitos e identificados por Olson. Com relação a esse ponto, aliás, convém lembrar as semelhanças entre as considerações desse autor e aquelas formuladas por Gaetano Mosca, no seu The Ruling Class (1939: 50), no que se refere à relação causal estabelecida por ambos entre tamanho do grupo e disposição para cooperar.

Em segundo lugar, os que elegem as elites como o ator político fundamental teriam resolvido o problema da "representação de interesses". Como se sabe, para os autores filiados a essa perspectiva, as elites não representam nenhum interesse que não sejam os seus próprios. É da natureza da explicação elitista considerar que os grupos assim definidos não agem na política em nome de outros grupos ou classes, mas apenas com o objetivo de promover a continuidade do seu domínio ou, se for o caso, com vistas a conquistar o poder (isto é, a agir como contra-elite $)^{17}$. Assim, não há qualquer

\footnotetext{
${ }^{16}$ Para não falar nas críticas mais usuais à teoria dos grupos de interesse, notadamente a propensão dessa teoria a fazer tábula rasa das diferenças estruturais entre os grupos sociais no que diz respeito à sua capacidade (potencialidade) para agir coletivamente. Cf. Offe e Wiesenthal, 1982: 61 e ss.

${ }^{17}$ Essa perspectiva que elimina a necessidade de estabelecer relações de representação de interesses entre as minorias politicamente ativas e grupos fora dela pode ser encontrada em autores com orientações normativas bastante diferentes, tais como
} 
exigência teórica de vincular o comportamento das elites políticas a interesses que se encontram fora do grupo.

A teoria das elites, porém, sofre de duas importantes limitações. Em primeiro lugar, os elitistas atribuem peso excessivo ao poder das elites políticas. Estas são consideradas como o agrupamento realmente responsável pela condução das comunidades humanas e não por outra razão são consideradas como o único objeto digno de estudo pelo cientista político. Nesse sentido, a abordagem elitista sofre de um voluntarismo excessivo e não é capaz de dar conta dos constrangimentos estruturais que limitam a ação das elites. Em segundo lugar, essa teoria é demasiadamente centrada nos interesses próprios das minorias politicamente ativas e, por isso, nunca elege como objeto de análise importante a relação que pode haver entre a conduta das elites e interesses externos a ela. O resultado desses dois problemas é que, na abordagem elitista, as minorias politicamente ati110 vas parecem agir em uma espécie de "vácuo social". Desse modo, os elitistas limitam-se a analisar ou a relação entre elite e massas (esta última nunca definida rigorosamente) ou a relação intra-elites. As classes sociais, ainda que sua existência seja reconhecida, não são levadas em conta na explicação do domínio político, por serem consideradas agregados demasiadamente amplos e que não produzem efeitos políticos importantes.

\section{À guisa de conclusão}

Como vimos anteriormente, há enormes dificuldades a serem resolvidas quando pretendemos usar o conceito de classe social para entender a dinâmica da política. Essas dificuldades foram reconhecidas por alguns autores, abordadas por outros, mas, parece, não foram solucionadas por ninguém. Como reagir a essa situação?

Mosca (1939), Pareto (1935), Michels (1982), Wright Mills (1981), Aron (1991). 
Uma primeira reação consiste em rejeitar a importância do conceito de classe social, na sua perspectiva marxista, para compreender as sociedades contemporâneas e, desse modo, simplesmente abandoná-lo em função de sua obsolescência. Essa postura, contudo, seria temerária, pois, para além dos debates ideológicos, não há consenso quanto a esse ponto (Wright; 1996; So, 1995). Ao contrário, há uma literatura que afirma exatamente o oposto (So, 1995: 320 e ss.). Se isso for verdade, então, o abandono do conceito de classe social seria tão-somente uma desistência.

Uma postura menos radical e, a meu ver, correta, consiste em rejeitar, pelas considerações de Olson Mancur, a tese de que a classe, como grande grupo, possa constituirse diretamente em um ator político coletivo. Nesse sentido, a teoria da escolha racional nos levaria a rechaçar categoricamente expressões como "a burguesia deseja”, "a classe operária quer”, “a pequena-burguesia almeja”, a não ser que tais expressões sejam uma espécie de taquigrafia que resuma interpretações de outra natureza. Caso contrário, afirmações desse tipo são, como lembra Bourdieu, presas da "ilusão intelectualista" que confunde a classe teórica com a classe real, uma ilusão que nunca consegue revelar a "misteriosa alquimia" (Bourdieu, 1989: 138) por meio da qual uma posição objetiva na estrutura social se transforma em uma personalidade coletiva em ação.

Desse modo, parece-me que a classe só pode se constituir como um conceito analiticamente rentável, se abandonarmos definitivamente a idéia de que ela age diretamente na política. Dito de outra forma, um uso adequado desse conceito parece exigir que se considere a classe como uma coletividade "representada" no campo político por uma "minoria politicamente ativa"18. O problema então é saber como detectar as relações de representação de classe no

\footnotetext{
${ }^{18}$ Quanto a este ponto, ver também Therborn, 1989: 437-438.
} 
funcionamento da luta política cotidiana, sem recorrer à chave-mestra das funções objetivas do Estado ou da lógica intrínseca do modo de produção.

Como vimos, em O 18 Brumário, Marx sugeriu duas formas de operacionalizar a idéia da classe como um ator político: a representação simbólica de classe e a representação subjetiva de classe.

No que diz respeito à "representação subjetiva de classe", alguns autores (por ex., Therborn, 1983 e 1989), além de Adam Przeworsky, fizeram sugestões metodológicas de como abordar a classe social como uma coletividade politicamente representada por uma minoria politicamente ativa (partido, sindicato, grupo político etc.). Creio que esse tipo de análise exige três procedimentos hierarquizados por ordem de importância para que se possa comprovar a tese da representação política de classe por uma minoria: a) o estudo do comportamento efetivo dessa minoria; b) a análise do conteúdo 112 do seu discurso e, por fim, c) estudo da origem social dos seus membros. Resumindo, é preciso saber se os membros da minoria em análise agem de maneira coordenada e conveniente aos interesses da classe que eles supostamente representam; se falam manifestamente em seu nome e se provêm da classe em questão. A hierarquização desses três procedimentos é importante, uma vez que eles têm impactos diferenciados na comprovação da relação de representação entre a minoria analisada e a classe que ela supostamente representa. Por exemplo, um grupo pode ser recrutado em uma classe (contemplando assim a exigência da origem social), mas ter um discurso e um comportamento orientados pela ideologia de outro grupo social; ao contrário, a presença de uma ação manifesta e conscientemente orientada pela consecução de objetivos de classe já seria suficiente para estabelecer a relação de representação, mesmo que os membros da minoria não fossem recrutados na classe em questão. Evidentemente, a presença das três dimensões tornaria a comprovação da 
existência de uma "representação subjetiva de classe" ainda mais sólida ${ }^{19}$.

Esse tipo de procedimento analítico apresenta duas importantes limitações. Primeiramente, dado o caráter altamente agregado do conceito marxista de classe social, esse tipo de análise é muito difícil de ser operacionalizada em sociedades em que a estrutura econômica e ocupacional é muito diversificada. Essa diversificação funcional traduz-se também, com freqüência, em diversificação e fragmentação dos interesses da classe por uma miríade de categorias profissionais. Por essa mesma razão, é mais fácil lançar mão desse procedimento analítico em relação às classes economicamente dominantes, sobretudo quando são a expressão de atividades altamente oligopolizadas, do que em relação às classes economicamente dominadas, por definição, muito mais diversificadas quanto à ocupação, aos interesses e aos esquemas ideológicos (Offe e Weisenthal, 1984).

Em segundo lugar, esse tipo de análise não consegue abordar o problema dos "efeitos" que a ação dessa minoria politicamente ativa pode produzir. Suponhamos que, valendo-nos dos três procedimentos indicados acima, cheguemos à conclusão que uma dada instituição funciona como representante de uma determinada classe no campo político. Suponhamos também que as opções políticas feitas por essa "elite de classe" produzem, ainda que inconscientemente, efeitos contrários aos interesses da classe que ela representa. Como resolver teoricamente essa situação em que um grupo se reconhece (e é reconhecido) abertamente como representante de classe, mas que, ao mesmo tempo, adota condutas cujos efeitos contrariam os interesses dos representados? Creio que a saída para esse paradoxo é diferenciar "ações de classe" de "ações com efeitos de classe" (Lafferty, 1996: 53). Uma ação de classe é uma ação manifestamente

\footnotetext{
${ }^{19}$ Tentamos algo parecido em Perissinotto, 2000.
} 
orientada com vistas a realizar um interesse de classe. Nesse caso, nem sempre os agentes que a realizam controlam plenamente todas as conseqüências de sua conduta, o que abre a possibilidade teórica para que efeitos contrários aos interesses da classe representada ocorram. Portanto, nem toda ação de classe produz, necessariamente, efeitos de classe. O contrário ocorre com "ações com efeitos de classe”. Essas ações podem ser realizadas por minorias que, em nenhum momento, reivindicam qualquer vínculo de classe, mas cujos efeitos são regularmente ${ }^{20}$ benéficos para os interesses de uma dada classe.

Creio que a "representação simbólica de classe" se situa nesse caso. Quando Eder (2002: 161) defende que a classe teórica só se transforma em classe real por meio de "esquemas interpretativos e classificatórios" que definem distinções de classe, ele, ao mesmo tempo, afirma que a maneira mais adequada de captar esse processo não é por meio de 114 uma análise da composição social dos ativistas políticos. A origem de classe não é garantia de que a ação coletiva promovida por esses ativistas seja de classe (2002: 274). Ainda que as proposições de Eder sejam feitas para pensar a relação entre os movimentos sociais e a classe média, creio que podem ser utilizadas também para outros casos.

Assim como a relação entre classes médias e movimentos sociais, creio que nenhuma classe social, sobretudo se definida como um grande grupo, se faz representar simbolicamente por apenas um grupo mobilizado. Qualquer classe pode ter "representantes políticos e literários" nas mais diversas instituições; vários grupos podem mobilizar-se e produzir um discurso e uma ação política cujos efeitos simbólicos favoreçam ou estigmatizem uma determinada classe. O problema fundamental é, dentro dessa miríade de grupos mobilizados,

\footnotetext{
${ }^{20} \mathrm{O}$ advérbio é importante para se evitar a "falácia dos benefícios", tal como definida por Dahl, 1988: 35.
} 
encontrar uma "unidade cultural" (Eder, 2002: 274) que possa ser generalizada para todos os grupos e, assim, identificada como uma "cultura de classe". Segundo Eder (2002: 276), essa unidade cultural deve ser entendida em termos de "interesses, normas e valores partilhados". O interesse refere-se à idéia de que os membros de classe sentem que obtêm menos ganho do que deveriam; as normas descrevem o quadro institucional que define o status dos membros da classe e, por fim, os valores medem o quanto as pessoas foram socializadas em uma mesma cultura e, por isso, aderem aos mesmos esquemas interpretativos e classificatórios.

Essa "sugestão analítica” parece-me extremamente interessante como forma de operacionalizar a análise de classe, sem cair no "instrumentalismo" ou no "funcionalismo". No entanto, não fica absolutamente claro como é possível realizar esse tipo de análise. Não ficam claros, sobretudo, os seguintes aspectos: a) como é possível identificar uma cultura de classe? Uma vez delimitada uma classe do ponto de vista objetivo, como é possível captar a sua visão de mundo? Devemos definir uma amostra aleatória e aplicar um survey com questões atitudinais? Devemos realizar análises qualitativas das produções simbólicas de alguns de seus membros? Devemos adotar todos esses procedimentos juntos? b) A representação simbólica de classe faz-se por meio de vários grupos, cujos membros não precisam ser recrutados na classe e, muito menos, falar abertamente em seu nome. Nesse sentido, essa "representação simbólica" nunca é direta, mas deve ser encontrada em traços específicos do discurso dos representantes que permitam identificar uma unidade cultural com a classe. Mas como fazer isso? Como provar que essas dimensões do discurso dos representantes expressam uma visão de classe? Como provar que elas produzem efeitos de classe?

Por fim, um outro problema da análise de classe diz respeito à identificação dos interesses de classe para que relações de representação possam ser comprovadas. No cam- 
po do marxismo, o problema dos interesses de classe foi predominantemente tratado por meio da oposição entre "interesses subjetivos" e "interesses objetivos". Contrários à perspectiva comportamentalista que afirma que os interesses de um grupo coincidem com as preferências manifestas de seus membros, os marxistas, em geral, defendem a idéia de que os interesses fundamentais de uma classe são aqueles inscritos na sua posição objetiva enquanto uma "potencialidade". São, nesse sentido, interesses objetivos que não se confundem, necessariamente, com a consciência psicológica dos membros empíricos da classe. Se, por um lado, a perspectiva comportamentalista despreza todas as questões relativas à "dominação simbólica”, a perspectiva do "interesse objetivo" é muito difícil de operacionalizar, pois, no mais das vezes, o "interesse objetivo de classe" constitui-se em uma atribuição arbitrária por parte do analista ou descreve interesses que nunca parecem vincular-se a padrões de ação 116 coletiva empiricamente verificáveis.

Quanto a esse problema, parece-me que as duas formas de operacionalizar a análise de classe vistas acima - a teoria da formação de classe e a teoria da unidade cultural - apontam caminhos mais adequados para abordar esse problema. Como ambas conferem lugar central ao processo histórico de constituição das classes, entendido como um processo permanente de luta, de organização, desorganização, reorganização das classes e de redefinição constante dos esquemas classificatórios, os "interesses de classe" não podem ser definidos a priori como um atributo de uma posição objetiva, nem serem tomados, de uma vez por todas, como preferências expressas por atores autônomos. Os interesses de classe são, assim, "socialmente construídos" (Rueschemeyer e Mahoney, 2000: 1586), no meio do processo de luta e em meio às relações de dominação que esse processo engendra.

Para as dificuldades de realização dessa tarefa, não é de menor importância, como já dissemos, o caráter alta- 
mente agregado do conceito de classe. Quanto a esse ponto, deve-se lembrar que Marx, no famoso último capítulo de O capital, sugere que o termo classe deve ser reservado para aqueles indivíduos que ocupam a mesma posição no processo produtivo capitalista, notadamente os trabalhadores assalariados produtivos, os capitalistas e os proprietários de terra. Desse modo, renda e ocupação funcional não poderiam ser critérios definidores da posição objetiva de classe (Marx, 1973: 817-18). Nessas condições, pensar a "representação subjetiva" e a "representação simbólica" de classe torna-se de fato muito difícil, dado o caráter extremamente agregado da classe social ${ }^{21}$. Por essa razão, Grusky e Sorensen (1998), por exemplo, defendem a desagregação do conceito de classe social em níveis ocupacionais como a única forma de operacionalizar a classe como uma unidade econômica, política e cultural.

Para finalizar, creio que são três os problemas de ordem metodológica que devem fazer parte da agenda de pesquisa dos estudiosos que lançam mão do conceito de classe social no marxismo: 1) pensar como é possível estabelecer relações de representação subjetiva de classe, discutindo procedimentos por meio dos quais podemos provar que uma "minoria politicamente ativa" constitui-se em um porta-voz de classe; 2) pensar instrumentos de análise que auxiliem na identificação de uma unidade cultural entre determinados grupos mobilizados na arena política e determinadas classes sociais situadas nas relações de produção; 3) pensar procedimentos por meio dos quais seria possível captar o processo histórico de construção dos interesses de classe.

\footnotetext{
${ }^{21}$ Não resolve o problema dizer que "classes definem-se em termo de um mapa estrutural de interesses materiais comuns baseados na exploração" e que por isso enfrentam objetivamente as mesmas estruturas de escolhas e as mesmas tarefas estratégicas quando pretendem melhorar o seu bem-estar econômico. Cf. Santos, 2002: 41. Essa postura não explicaria, por exemplo, porque operários que ocupam a mesma posição nas relações materiais podem desejar coisas tão díspares como aumento salarial, fascismo ou socialismo.
} 
Creio que qualquer um desses objetivos só poderá ser satisfatoriamente realizado (ou definitivamente abandonado) por meio de estudos empíricos aprofundados que se proponham a testar a hipótese de que as classes são atores políticos importantes.

\section{Renato Monseff Perissinotto}

é professor adjunto do Departamento de Ciências Sociais da Universidade Federal do Paraná

\section{Referências bibliográficas}

ANDERSON, Perry. 1985. Teoria, politica e historia: um debate com E. P. Thompson. México: Siglo XXI.

ARON, Raymond. 1991. "Classe social, classe política, classe dirigente". Estudos Sociológicos. Rio de Janeiro: Bertrand Brasil: 260-281.

ARTOUS, A. 1999. Marx, L'Etat et la politique. Paris: Syllepse.

BLOCK, Fred. 1987. Revising State theory: essays in politics and postindustrialism. Philadelphia: Temple University Press, p. 3-35.

118 BOURDIEU, Pierre. 2001. "Os três estados do capital cultural”. In: NOGUEIRA, M. A.; CATANI, A. (orgs.). Escritos de educação. Petrópolis-RJ: Vozes, p. 73-79.

. 1989. "Espaço social e gênese das 'classes'”. In: O poder simbólico. Lisboa: Difel, p. 133-161.

Les Éditions de Minuit.

. 1989a). La noblesse d'État: grandes écoles et esprit de corps. Paris:

. 2003. "Condição de classe e posição de classe". In: Economia das trocas simbólicas. São Paulo: Perspectiva, p. 3-25.

. 2004. "The mistery of the ministry: from particular wills to the general will”. Constellations, vol. 11, n. 1, p. 37-43.

COHEN, G. A. 1982. "Reply to Elster on "Marxism, Functionalism, and Game Theory". Theory and society, 11 (4): 483-495.

DAHL, Robert. 1988. Análise política moderna. Brasília: UNB. 1997. Poliarquia. São Paulo: Edusp.

EDER, Klaus. 2002. A nova política de classe. Bauru-SP: Edusc.

ELSTER, John. 1982. "Marxism, functionalism, and game theory". Theory and society, 11 (4): 453-482.

FAUSTO, Ruy. 1987. "Sobre as classes”. In: FAUSTO, R. Marx: lógica e política. São Paulo, Brasiliense. Tomo II, p. 201-286. 
GONZÁLEZ, Sabrina. 2006. "Introducción: crónicas marxianas de uma muerte anunciada”. In: BORON, A.; AMADEO, J.; GONZÁLEZ, S. (comps.). La teoría marxista hoy: problemas y perspectivas. Buenos Aires: Clacso Libros, p. 15-33.

GRUSKY, David B.; SORENSEN, Jesper B. 1998. "Can class analysis be salvaged?”. The American Journal of Sociology, vol. 103, n. 5, March.

HOLLOWAY, J.; PICCIOTO, S. (eds.). 1978. State and capital: a marxist debate. London: Arnold.

KAPLAN, Abraham; LASSWELL, Harold. 1998. Poder e sociedade. Brasília: Editora da UnB.

LAFFERTY, George. 1996. "Class, politics, and social theory: the possibilities in marxist analysis”. Critical sociology, vol. 22, Issue 2 , p. 51-65.

MAGUIRE, J. M. 1984. Marx y su teoría de la política. México: Fondo de Cultura Económico.

MARX, K. [1852]1984. O 18 Brumário de Louis Bonaparte. 2. ed. Lisboa: Avante.

[1894] 1973. El capital. Crítica de la economia política. México: Fondo de Cultura Económica.

MCLENNAN, Gregor. 1989. Marxism, pluralism and beyond. Cambridge: Polity Press.

MICHELS, Robert. 1982. Sociologia dos partidos políticos. Brasília: UnB.

MILIBAND, Ralph. 1983. "State power and class interests". In: Class power and State power. Londres: Verso/NLB, p. 63-78.

. 1996. “Análise de classes”. In: GIDDENS, A.; TURNER, J. (orgs.).

Teoria social hoje. São Paulo: Ed. Unesp: 471-502.

MOSCA, Gaetano. 1939. The ruling class. Elementi di scienza politica. New York/Toronto/London: McGraw-Hill.

MYLES, John; TUREGUN, Adnan. 1994. "Comparative studies in class structure”. Annual Review of Sociology, vol. 20: 103-122.

OFFE, Claus. 1984. "Dominação de classe e sistema político. Sobre a seletividade das instituições políticas”. In: Problemas estruturais do Estado capitalista. Rio de Janeiro: Tempo Brasileiro, p. 140-177.

; RONGE, Volker. 1984. "Teses sobre a fundamentação do conceito de Estado capitalista e sobre a pesquisa política de orientação materialista”. In: Problemas estruturais do Estado capitalista. Rio de Janeiro: Tempo Brasileiro, p. 122-139.

; WEISENTHAL, Helmut. 1984. "Duas lógicas da ação coletiva: anotações teóricas sobre a classe social e a forma organizacional”. In: Problemas estruturais do Estado capitalista. Rio de Janeiro: Tempo Brasileiro, p. 56-118. 
OLSON, Mancur. 1999. A lógica da aşão coletiva. São Paulo: Edusp.

PARETO, Vilfredo. 1935. The mind and society [Trattato di Sociologia generale]. Harcourt, Brace and Company, New York: Edited by Arthur Livingston. 4 vol.

PERISSINOTTO, R. M. 2000. Estado e capital cafeeiro em São Paulo (18891930). 1. ed. São Paulo: Annablume/Fapesp. v. 2.

POULANTZAS, Nicos. 1978. As classes sociais no capitalismo hoje. Rio de Janeiro, Zahar Editora.

POULANTZAS, Nicos. 1986. Poder político e classes sociais. Rio de Janeiro, Martins Fontes.

PRZEWORSKY, Adam. 1989. "A organização do proletariado em classe: o processo de formação de classes”. In: Capitalismo e social-democracia. São Paulo: Companhia das Letras, 1989.

ROEMER, John E. 1982. "Methodological Individualism and Deductive Marxism”. Theory and Society, 11 (4): 513-520.

. 1989. "Nuevas direcciones en la teoria marxista de las clases sociales". In: ROEMER, John E. (comp.). El marxismo: una perspective analítica. México: Fondo de Cultura Económica, p. 97-132.

RUESCHEMEYER, Dietrich; MAHONEY, James. 2000. "A Neo-Utilitarian Theory of Class? Aage Sorensen's Structural Theory of Inequality". The American Journal of Sociology, May, vol. 105.

SALLUM JUNIOR, Brasílio. 2005. "Classes, cultura e ação coletiva”. Lua Nova, São Paulo, 65: 11-42.

SANTOS, José Alcides Figueiredo. 2002. Estrutura de posições de classe no Brasil: Mapeamento, mudanças e efeitos na renda. Belo Horizonte/Rio de Janeiro, Editora da UFMG/Iuperj.

SCHATTSCHNEIDER, E. E. 1975. The semisovereing people: A realist's view of democracy in America. Harcourt Brace Jovanovich College Publishers: Fort Worth. SO, Alvin Y. 1995. "Recent developments in marxist class analysis: a critical appraisal”. Sociological inquiry, vol. 65, n 3/4, november.

THERBORN, G. 1983. "Why some classes are more successful than others?”. New Left Review, 138, p. 37-55.

. 1989. "A análise de classe no mundo atual: o marxismo como ciência social”. In: HOBSBAWN, E. (org.). História do marxismo. Rio de Janeiro: Paz e Terra. vol. 11, p. 389-439.

THOMPSON, E. P. 1981. A miséria da teoria. Rio de Janeiro: Zahar. 1987. A formação da classe operária inglesa. Rio de Janeiro: Paz e Terra.

TRUMAN, David. 1951. The governmental process: political interest and public opinion. New York: Alfred A. Knopf. 
WIPPLER, Reinhard. 1993. "Individualisme méthodologique et action collective". In: F. Chazel. (dir.). Action collective et mouvements sociaux. Paris, PUF. WOOD, Ellen M. 2003) "Classe como processo e como relação". In: Democracia contra Capitalismo. São Paulo: Boitempo Editorial, p. 73-98.

WRIGHT MILLS, C. 1981. A elite do poder. 4. ed. Rio de Janeiro, Zahar.

WRIGHT, Eric 0. 1985. Classes. London: New Left Books. . 1979. Classe, crise e o Estado. Rio de Janeiro: Zahar. . 1993. "Class analysis, history and emancipation". New Left Review. 202, p. $15-36$. . 1996. "The continuing relevance of class analysis - comments". Theory and Society, 25, p. 693-716. 


\section{O 18 BRUMÁRIO E A ANÁLISE DE CLASSE CONTEMPORÂNEA}

\section{RENATO MONSEFF PERISSINOTTO}

Este artigo considera O 18 Brumário de Louis Bonaparte uma espécie de súmula que condensa todas as dificuldades inerentes à análise de classe da política. $\mathrm{O}$ artigo está dividido em cinco partes. Na primeira, são analisadas as passagens de $O$ 18 Brumário que enunciam algumas proposições fundamentais acerca da análise política de classe; na segunda, mostra-se que a literatura marxista contemporânea não solucionou os problemas identificados em relação às proposições marxianas; as terceira e quarta partes discutem algumas perspectivas alternativas (classistas e não-classistas) ao marxismo; por fim, à guisa de conclusão, faz-se algumas reflexões sobre modos possíveis de operacionalizar a análise de classe da política e sobre os problemas a serem enfrentados nesses casos.

Palavras-chave: $O 18$ de Brumário de Louis Bonaparte; Análise de classe contemporânea; Marxismo.

\section{THE EIGHTEENTH BRUMAIRE AND THE CONTEMPORARY CLASS ANALYSIS}

This article considers The Eighteenth Brumaire of Louis Napoleon a kind of summary which condenses all the inherent difficulties to the class analysis of Politics. The article is divided in four parts. In the first part, it analyses some passages of The Eighteenth Brumaire that enunciate some fundamental propositions on class analysis of Politics; secondly, it asserts that contemporary Marxist literature on class has not solved the problems here pointed out; in the third and forth parts it discusses some class and non-class perspectives alternative to Marxism; at last, it 
essays some reflections on possible ways of elaborating with the class analysis of Politics and the problems to be overcome in those cases. Keywords: The Eighteenth Brumaire of Louis Napoleon; Contemporary class analysis; Marxism. 